Sains Malaysiana 47(7)(2018): 1607-1615

http://dx.doi.org/10.17576/jsm-2018-4707-32

\title{
Mathematical Model of Mixed Convection Boundary Layer Flow over a Horizontal Circular Cylinder Filled in a Jeffrey Fluid with Viscous Dissipation Effect \\ (Model Matematik bagi Aliran Lapisan Sempadan Olakan Campuran melalui Silinder Bulat Mengufuk Diisi dalam Bendalir Jeffrey dengan Kesan Pelesapan Likat)
}

\author{
SYAZWANI MOHD ZOKRI, NUR SYAMILAH ARIFIN, MUHAMMAD KHAIRUL ANUAR MOHAMED \\ ABDUL RAHMAN MOHD KASIM,NURUL FARAHAIN MOHAMMAD \\ \& MOHD ZUKI SALLEH*
}

\begin{abstract}
This paper delves into the problem of mixed convection boundary layer flow from a horizontal circular cylinder filled in a Jeffrey fluid with viscous dissipation effect. Both cases of cooled and heated cylinders are discussed. The governing equations which have been converted into a dimensionless form using the appropriate non-dimensional variables are solved numerically through the Keller-box method. A comparative study is performed and authentication of the present results with documented outcomes from formerly published works is excellently achieved. Tabular and graphical representations of the numerical results are executed for the specified distributions, considering the mixed convection parameter, Jeffrey fluid parameters and the Prandtl and Eckert numbers. Interestingly, boundary layer separation for mixed convection parameter happens for some positive (assisting flow) and negative (opposing flow) values. Strong assisting flow means the cylinder is heated, which causes the delay in boundary layer separation, whereas strong opposing flow means the cylinder is cooled, which conveys the separation point close to the lower stagnation point. Contradictory behaviours of both Jeffrey fluid parameters are observed over the velocity and temperature profiles together with the skin friction coefficient and Nusselt number. The increase of the Prandtl number leads to the decrement of the temperature profile, while the increase of the Eckert number results in the slight increment of the skin friction coefficient and decrement of the Nusselt number. Both velocity and temperature profiles of Eckert number show no effects at the lower stagnation point of the cylinder.
\end{abstract}

Keywords: Boundary; horizontal circular cylinder; Jeffrey fluid; layer separation; viscous dissipation

ABSTRAK

Kertas ini membincangkan masalah aliran lapisan sempadan olakan campuran ke atas silinder bulat mengufuk dalam bendalir Jeffrey dengan kesan pelesapan likat. Kedua-dua kes silinder yang disejuk dan dipanaskan dibincangkan. Persamaan menakluk yang telah ditukarkan kepada bentuk tak bermatra menggunakan pemboleh ubah penjelmaan tak bermatra yang sesuai diselesaikan secara berangka melalui kaedah kotak Keller. Kajian perbandingan dijalankan dan pengesahan keputusan sekarang dengan hasil yang telah didokumenkan daripada kerja yang diterbitkan sebelum ini dicapai dengan baik. Perwakilan jadual dan grafik bagi keputusan berangka dijalankan untuk taburan yang ditentukan, mengambil kira parameter olakan campuran, parameter bendalir Jeffrey dan nombor Prandtl dan Eckert. Menariknya, pemisahan lapisan sempadan untuk parameter olakan campuran berlaku untuk beberapa nilai positif (aliran membantu) dan negatif (aliran menentang). Aliran membantu yang kuat bermaksud silinder dipanaskan yang menyebabkan kelewatan dalam pemisahan lapisan sempadan, manakala aliran menentang yang kuat bermaksud silinder disejukkan yang membawa titik perpisahan dekat kepada titik genangan bawah. Tingkah laku yang bercanggah pada kedua-dua parameter bendalir Jeffrey diperhatikan melalui profil halaju dan suhu bersama-sama dengan pekali geseran kulit dan nombor Nusselt. Peningkatan nombor Prandtl menyebabkan pengurangan profil suhu, manakala peningkatan nombor Eckert menyebabkan sedikit kenaikan pada pekali geseran kulit dan penurunan nombor Nusselt. Kedua-dua profil halaju dan suhu nombor Eckert tidak memberi kesan pada titik genangan bawah silinder.

Kata kunci: Bendalir Jeffrey; pelesapan likat; pemisahan lapisan sempadan; silinder bulat mengufuk

\section{INTRODUCTION}

The occurrence of mixed convection flow requires the engagement of free and forced convection flows, where either the buoyancy force effect in forced convection or the forced flow effect in free convection happens to be substantial. Commonly, the flow impact of free convection to that of forced convection is measured by buoyancy parameter $\gamma$. The forced convection is dominant when 
$\gamma \rightarrow 0$ while free convection is dominant when $\gamma \rightarrow \infty$. From theoretical and engineering applications perspectives, the investigation of convective boundary layer flow and heat transfer over an immersed body (flat plates, cylinders and spheres) is essential by virtue of highly substantial effects of viscosity and friction adjacent to the surface. In fact, more information about the flow separation from the surface up to the separation point can be obtained through the boundary layer equations (Nazar 2003). This research area is currently in the limelight due to the enormous applications in the manufacturing industry including polymer processing, cooling of elastic sheet, fibre technology and plastic manufacturing. In polymer processing, for example, fluid mechanics and heat transfer have always been the critical subjects in specifying the components of manufactured polymers. Polymer flows, on account of their complex structure, are specifically differed from the purely viscous fluids like water or oil by their highly viscous, viscoelasticity and commonly non-Newtonian in nature (George 2009). Some vital features of polymers are retardation, relaxation and elongational viscosity. In many instances, exploitation of polymers by most industrial flow processes is normally laminar in nature, attributable to their high viscosity level (Baaijens et al. 1997).

More sophisticated mathematical models to express the interconnection between the shear stress and strain are required to particularise the rheological behaviour of polymers. In that event, many theoretical and computational studies focusing on fluid flow and heat transfer characteristics have been put forward on the transport phenomena from cylindrical bodies (Merkin 1977; Merkin \& Pop 1988; Rotte \& Beek 1969). Following Merkin (1977), the study of micropolar and viscoelastic fluids with the constant wall temperature was extended by Anwar et al. (2008) and Nazar et al. (2003), respectively. Rashad et al. (2013) focused on the nanofluid model with the convective boundary condition. A number of investigations have been engrossed on the non-Newtonian fluid since then (Hayat et al. 2015; Kasim et al. 2013; Prasad et al. 2014). Among the established non-Newtonian fluid models, the model of Jeffrey fluid is theoretically practical for exemplifying both relaxation and retardation effects, which is relevant to the complex polymer flow. This model originates from the Maxwell model and assimilates a time derivative of the strain rate, where the retardation time parameter is precisely involved in the model alteration. In addition, high shear viscosity, shear thinning and yield stress are the important features of this fluid model. This model also facilitates numerical computation since it exploits time derivatives instead of convected derivatives. Prasad et al. (2015) studied the Jeffrey fluid model past a permeable horizontal circular cylinder embedded in the nonDarcy porous medium, while Rao et al. (2015) considered the same fluid model over a permeable non-isothermal wedge with mixed convection. Several important works regarding this fluid model were scrutinized by Gaffar et al. (2015), Subba et al. (2017) and Zin et al. (2017).

Most often, the viscous dissipation effect is neglected due to its small or almost negligible outcome. However, this supposition is possibly true for some cases, but may not be necessarily valid to all boundary layer flow problems, especially when confronting with highly viscous fluid even at moderate velocity or fluid that flows very fast (Morini 2013). Indeed, the convective heat transfer is, to a great extent, being controlled by the fluid rheological behaviour. Gebhart (1962) tackled the impact of viscous dissipation over a vertical surface. The same effect was then examined by Yirga and Shankar (2013) in a nanofluid induced by a stretching sheet. Mohamed et al. (2016) tackled the viscous dissipation effect from a horizontal circular cylinder in a viscous fluid. Of late, Ferdows et al. (2017) explored the viscous dissipation effect on the boundary layer flow and heat transfer from a stretching sheet.

In view of the above-mentioned literatures, the present study aims to analyse the viscous dissipation effect on mixed convection boundary layer flow from a horizontal circular cylinder filled in a Jeffrey fluid. Prior to the numerical solutions via the Keller-box method, the non-dimensional variables are first applied to convert the governing equations into a dimensionless form. The boundary layer separation is scrutinized for both cases of cooled and heated cylinders. The results for velocity and temperature profiles, together with the skin friction coefficient and Nusselt number are illustrated in tabular and graphical forms for some emerging parameters.

\section{MATHEMATICAL FORMULATION}

The present investigation is confined to the flow of a steady mixed convection boundary layer in a uniform stream flowing vertically upwards across a horizontal circular cylinder of radius $a$ in a Jeffrey fluid. Figure 1 displays the flow model and coordinate system where the $\bar{x}$-axis is directed along the cylinder surface from the lower stagnation point, $\bar{x}=0$ while the $\bar{y}$-axis is oriented perpendicular to the surface. It is supposed that $T_{w}$ and $T_{\infty}$ are the respective constant and ambient temperatures, for which $T_{w}>T_{\infty}$ signifies assisting flow (heated cylinder) whereas $T_{w}<T_{\infty}$ represents opposing flow (cooled cylinder). The gravitational acceleration and free stream velocity are denoted as $g$ and $U_{\infty}$, respectively. The Boussinesq and boundary layer approximations are assumed to be valid and the governing equations are introduced correspondingly as (Das et al. 2015; Nazar et al. 2003):

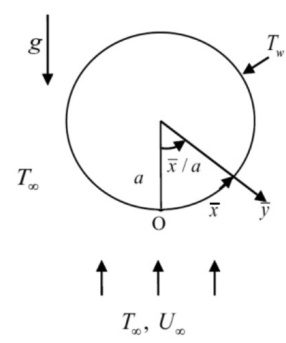

FIGURE 1. Flow model and the coordinate system 


$$
\begin{aligned}
& \frac{\partial \bar{u}}{\partial \bar{x}}+\frac{\partial \bar{v}}{\partial \bar{y}}=0 \\
& \bar{u} \frac{\partial \bar{u}}{\partial \bar{x}}+\bar{v} \frac{\partial \bar{u}}{\partial \bar{y}}=\bar{u}_{e} \frac{d \bar{u}_{e}}{d \bar{x}}+\frac{v}{1+\lambda} \\
& {\left[\frac{\partial^{2} \bar{u}}{\partial \bar{y}^{2}}+\lambda_{1}\left(\bar{u} \frac{\partial^{3} \bar{u}}{\partial \bar{x} \partial \bar{y}^{2}}+\frac{\partial \bar{u}}{\partial \bar{y}} \frac{\partial^{2} \bar{u}}{\partial \bar{x} \partial \bar{y}}\right.\right.} \\
& \left.\left.-\frac{\partial \bar{u}}{\partial \bar{x}} \frac{\partial^{2} \bar{u}}{\partial \bar{y}^{2}}+\bar{v} \frac{\partial^{3} \bar{u}}{\partial \bar{y}^{3}}\right)\right]+\ldots \\
& g \beta\left(T-T_{\infty}\right) \sin \frac{\bar{x}}{a}, \\
& \bar{u} \frac{\partial T}{\partial \bar{x}}+\bar{v} \frac{\partial T}{\partial \bar{y}}=\alpha \frac{\partial^{2} T}{\partial \bar{y}^{2}}+\frac{v}{C_{p}(1+\lambda)} \\
& {\left[\left(\frac{\partial \bar{u}}{\partial \bar{y}}\right)^{2}+\lambda_{1}\left(\bar{v} \frac{\partial \bar{u}}{\partial \bar{y}} \frac{\partial^{2} \bar{u}}{\partial \bar{y}^{2}}+\bar{u} \frac{\partial \bar{u}}{\partial \bar{y}} \frac{\partial^{2} \bar{u}}{\partial \bar{x} \partial \bar{y}}\right)\right],}
\end{aligned}
$$

with the boundary conditions (Merkin 1977)

$$
\begin{aligned}
& \bar{u}(\bar{x}, 0)=\bar{v}(\bar{x}, 0)=0, T(\bar{x}, 0)=T_{w} \text { at } \bar{y}=0 \\
& \bar{u}(\bar{x}, \infty) \rightarrow \bar{u}_{e}, \bar{v}(\bar{x}, \infty) \rightarrow 0, T(\bar{x}, \infty) \rightarrow T_{\infty} \text { as } \bar{y} \rightarrow \infty
\end{aligned}
$$

where $\bar{u}$ and $\bar{v}$ denote the respective velocity components along the $\bar{x}$ and $\bar{y}$ axes. Next, $v, \alpha, \mu, \beta, \lambda, C_{p}, \lambda, T$ and $\rho$ are the respective kinematic viscosity, thermal diffusivity, dynamic viscosity, thermal expansion, ratio of relaxation to retardation times, specific heat capacity at a constant pressure, relaxation time, local temperature and fluid density. The velocity of the external flow is denoted as $\bar{u}_{e}(x)=U_{\infty} \sin (\bar{x} / a)$. The following variables are then imposed to transform (1) to (4) into the dimensionless form

$$
\begin{aligned}
& x=\frac{\bar{x}}{a}, y=\operatorname{Re}^{1 / 2} \frac{\bar{y}}{a}, u=\frac{\bar{u}}{U_{\infty}}, v=\operatorname{Re}^{1 / 2} \frac{\bar{v}}{U_{\infty}}, \\
& \theta(\eta)=\frac{\left(T-T_{\infty}\right)}{\left(T_{w}-T_{\infty}\right)}, u_{e}(x)=\frac{\bar{u}_{e}(x)}{U_{\infty}}
\end{aligned}
$$

Substituting (5) into (1) to (4), this yield

$$
\begin{aligned}
\frac{\partial u}{\partial x}+\frac{\partial v}{\partial y}=0, & \\
u \frac{\partial u}{\partial x}+v \frac{\partial u}{\partial y}= & u_{e} \frac{d u_{e}}{d x}+\frac{1}{1+\lambda} \\
& {\left[\frac{\partial^{2} u}{\partial y^{2}}+\lambda_{2}\left(u \frac{\partial^{3} u}{\partial x \partial y^{2}}+\frac{\partial u}{\partial y} \frac{\partial^{2} u}{\partial x \partial y}\right.\right.} \\
& \left.\left.-\frac{\partial u}{\partial x} \frac{\partial^{2} u}{\partial y^{2}}+v \frac{\partial^{3} u}{\partial y^{3}}\right)\right]+\gamma \theta \sin x
\end{aligned}
$$

$$
\begin{aligned}
& u \frac{\partial \theta}{\partial x}+v \frac{\partial \theta}{\partial y}=\frac{1}{\operatorname{Pr}} \frac{\partial^{2} \theta}{\partial y^{2}}+\frac{E c}{(1+\lambda)}\left[\left(\frac{\partial u}{\partial y}\right)^{2}+\lambda_{2}\right. \\
& \left.\left(u \frac{\partial u}{\partial y} \frac{\partial^{2} u}{\partial x \partial y}+v \frac{\partial u}{\partial y} \frac{\partial^{2} u}{\partial y^{2}}\right)\right], \\
& u(x, 0)=0, v(x, 0)=0, \theta(x, 0)=1 \text { at } y=0 \\
& u(x, \infty) \rightarrow u_{e}, v(x, \infty) \rightarrow 0, \theta(x, \infty) \rightarrow 0 \text { as } y \rightarrow \infty
\end{aligned}
$$

where $\lambda_{2}=\frac{\lambda_{1} U_{\infty}}{a}$ is Deborah number, $\operatorname{Pr}=\frac{\mu}{\alpha \rho}$ is Prandtl number, $E c=\frac{U_{\infty}{ }^{2}}{C_{p}\left(T_{w}-T_{\infty}\right)}$ is Eckert number, $\gamma=\frac{G r}{\operatorname{Re}^{2}}$ mixed convection parameter, $\mathrm{Re}=\frac{U_{\infty} a}{V}$ is Reynolds number and $G r=\frac{g \beta\left(T_{w}-T_{\infty}\right) a^{3}}{V^{2}}$ is Grashof number. Following Merkin (1977), equations (6) to (8) with boundary conditions (9) are solved by seeking the subsequent solutions:

$$
\psi=x f(x, y) \quad \theta=\theta(x, y),
$$

where $\psi$ implies the stream function which is specified in a common way as: $u=\frac{\partial \psi}{\partial y}$. and $v=-\frac{\partial \psi}{\partial x}$, while $\theta$ symbolizes the rescaled dimensionless temperature of the fluid. Now, (6) is automatically fulfilled, while (7) to (9) become

$$
\begin{aligned}
& \frac{1}{1+\lambda} f^{\prime \prime \prime}+f f^{\prime \prime}-\left(f^{\prime}\right)^{2}+\frac{\sin x}{x}(\cos x+\gamma \theta)+\frac{\lambda 2}{1+\lambda}\left[\left(f^{\prime \prime}\right)^{2}-f f^{(i v)}\right]= \\
& x\left[f^{\prime} \frac{\partial f^{\prime}}{\partial x}-\frac{\partial f}{\partial x} f^{\prime \prime}+\frac{\lambda 2}{1+\lambda}\left(\frac{\partial f}{\partial x} f^{(i v)}-f^{\prime} \frac{\partial f^{\prime \prime \prime}}{\partial x}+\frac{\partial f^{\prime}}{\partial x} f^{\prime \prime \prime}-f^{\prime \prime} \frac{\partial f^{\prime \prime}}{\partial x}\right)\right],
\end{aligned}
$$

$$
\begin{aligned}
\frac{1}{\operatorname{Pr}} \theta^{\prime \prime}+f \theta^{\prime}= & x\left[f^{\prime} \frac{\partial \theta}{\partial x}-\frac{\partial f}{\partial x} \theta^{\prime}-x \frac{E c}{(1+\lambda)}\right. \\
& \left(\left(f^{\prime \prime}\right)^{2}+\lambda_{2}\left(f^{\prime}\left(f^{\prime \prime}\right)^{2}+x f^{\prime \prime \prime} \frac{\partial f^{\prime \prime}}{\partial x}\right.\right. \\
& \left.\left.\left.-f f^{\prime \prime} f^{\prime \prime \prime}-x \frac{\partial f}{\partial x} f^{\prime \prime} f^{\prime \prime \prime}\right)\right)\right],
\end{aligned}
$$

$$
\begin{aligned}
& f(x, 0)=0, \quad f^{\prime}(x, 0)=0, \quad \theta(x, 0)=1 \text { at } y=0 \\
& f^{\prime}(x, \infty) \rightarrow \frac{\sin x}{x}, \quad f^{\prime \prime}(x, \infty) \rightarrow 0, \quad \theta(x, \infty) \rightarrow 0 \quad \text { as } y \rightarrow \infty
\end{aligned}
$$

where primes represent differentiation with respect to $y$. At $x \approx 0$, the location is at the lower stagnation point of cylinder. Consequently, (11) to (13) give rise to 


$$
\frac{1}{1+\lambda} f^{\prime \prime \prime}-\left(f^{\prime}\right)^{2}+f f^{\prime \prime}+\frac{\lambda 2}{1+\lambda}\left[\left(f^{\prime \prime}\right)^{2}-f f^{(i v)}\right]+1+\gamma \theta=0,
$$

$\frac{1}{\operatorname{Pr}} \theta^{\prime \prime}+f \theta^{\prime}=0$,

$$
\begin{aligned}
& f(0)=0, f^{\prime}(0)=0, \theta(0)=1 \\
& f^{\prime}(\infty) \rightarrow 1, f^{\prime \prime}(\infty) \rightarrow 0, \theta(\infty) \rightarrow 0
\end{aligned}
$$

The physical quantities of interests are the local skin friction coefficient $C_{f}$ and the local Nusselt number $N u_{x}$,

$$
C_{f}=\frac{\tau_{w}}{\rho U_{\infty}^{2}}, \quad N u_{x}=\frac{a q_{w}}{k\left(T_{w}-T_{\infty}\right)}
$$

Using (5) and (10), (17) becomes

$$
\begin{aligned}
C_{f} \mathrm{Re}_{x}{ }^{1 / 2}= & \frac{1}{1+\lambda}\left[x f^{\prime \prime}(x, 0)+\lambda_{2}\right. \\
& \left.\left\{\begin{array}{l}
x^{2} f^{\prime}(x, 0) f^{\prime \prime}(x, 0) \frac{\partial f}{\partial x}-x f(x, 0) f^{\prime \prime \prime}(x, 0) \\
+x f^{\prime}(x, 0) f^{\prime \prime}(x, 0)-x^{2} f^{\prime \prime \prime}(x, 0) \frac{\partial f}{\partial x}
\end{array}\right\}\right]
\end{aligned}
$$

and

$$
N u_{x} \operatorname{Re}_{x}^{-1 / 2}=-\theta^{\prime}(x, 0)
$$

where $\tau_{w}=\frac{\mu}{1+\lambda}\left[\frac{\partial \bar{u}}{\partial \bar{y}}+\lambda_{1}\left(\bar{u} \frac{\partial^{2} \bar{u}}{\partial \bar{x} \partial \bar{y}}+\bar{v} \frac{\partial^{2} \bar{u}}{\partial \bar{y}^{2}}\right)\right]_{\bar{y}=0}$ (Das et al. 2015) and $q_{w}=-k\left(\frac{\partial T}{\partial \bar{y}}\right)_{\bar{y}=0}$ are defined as surface shear stress and surface heat flux, respectively, on condition that $\mu=\rho v$ and $k$ being the respective dynamic viscosity and thermal conductivity.

\section{NUMERICAL METHODS}

Computational solution is developed using the Keller-box method to solve the partial differential equations (11) and (12) with boundary conditions (13). The essential steps of this method are: reduce equations (11) to (13) into first order system, write in the finite difference form: discretise using three-point central difference derivatives, Newton method: linearise the resulting non-linear equations and Block tridiagonal method: solve the resulting system of linear equations. All parameters used for the simulation are defaulted as follows (unless mentioned otherwise): Pr $=0.71, E c=\lambda_{2}=0.1$ and $\gamma=0.1$, with step size of 0.02 in the $x$ and $y$ directions and the boundary layer thickness of $y_{\infty}=8$. In order to validate the results attained through this attempt, they are assessed against those of Merkin (1977), Nazar et al. (2003) and Rashad et al. (2013) for several values of $\lambda$, as accessible in Table 1 . As shown, the results are perceived to be very much in line and such consistency offers confidence to the authors to proceed with the numerical results.

\section{RESULTS AND DISCUSSION}

A comprehensive study is presented in the form of tables (Tables 2 and 3) and figures (Figures 2 to 12). In Tables 2 and 3 , both variations of skin friction coefficient $C_{f} \operatorname{Re}_{x}^{1 / 2}$ and Nusselt number $N u_{x} \operatorname{Re}_{x}^{-1 / 2}$ against $x$ for different values of mixed convection parameter, $\gamma$ are inspected. As $\gamma$ increases, the $C_{f} \operatorname{Re}_{x}^{1 / 2}$ is also increased, as displayed in Table 2. This is due to a favourable pressure gradient instigated by the buoyancy forces that aid in the development of fluid flow and boundary layer thickness. The wall shear stress turns out to be greater, thus, causing the upsurge in the $C_{f} \operatorname{Re}_{x}^{1 / 2}$. Similar to Table 2, the favourable pressure gradient also stimulates the increase of $N u_{x} \operatorname{Re}_{x}^{-1 / 2}$, which physically implies the improvement of the convective heat transfer from the cylinder surface (Table 3). Such outcomes are conceivably anticipated as it coincides with the predicted impact of favourable pressure gradient (Anwar et al. 2008). From these tables, it can also be deduced that the boundary layer separation

TABLE 1. Comparative study of $-\theta^{\prime}(0)$ with existing publications for dissimilar values of $\gamma$ when $\operatorname{Pr}=1.0, E c=0, \lambda=0$ and $\lambda_{2} \rightarrow 0$ (very small)

\begin{tabular}{ccccc}
\hline \multicolumn{5}{c}{$-\theta^{\prime}(0)$} \\
\hline$\gamma$ & Merkin (1977) & Nazar et al. (2003) & Rashad et al. (2013) & Present \\
\hline-1.0 & 0.5067 & 0.5080 & 0.5068 & 0.506679 \\
-0.5 & 0.5420 & 0.5430 & 0.5421 & 0.542072 \\
0.0 & 0.5705 & 0.5710 & 0.5706 & 0.570484 \\
0.5 & 0.5943 & 0.5949 & 0.5947 & 0.594546 \\
0.88 & 0.6096 & 0.6112 & 0.6111 & 0.610775 \\
0.89 & 0.6110 & 0.6116 & 0.6114 & 0.611182 \\
1.0 & 0.6158 & 0.6160 & 0.6160 & 0.615601 \\
2.0 & 0.6497 & 0.6518 & 0.6518 & 0.651507 \\
5.0 & 0.7315 & 0.7320 & 0.7319 & 0.731529 \\
\hline
\end{tabular}


TABLE 2. Variation of $C_{f} \operatorname{Re}_{x}^{1 / 2}$ for several values of $x$ and $\gamma$

\begin{tabular}{ccccccccc}
\hline$x \mid \gamma$ & -1.0 & -0.5 & 0.0 & 0.5 & 1.85 & 1.86 & 3.0 & 5.0 \\
\hline $0^{\circ}$ & 0.000000 & 0.000000 & 0.000000 & 0.000000 & 0.000000 & 0.000000 & 0.000000 & 0.000000 \\
$10^{\circ}$ & 0.103121 & 0.161853 & 0.214825 & 0.264133 & 0.385758 & 0.386612 & 0.480764 & 0.634175 \\
$20^{\circ}$ & 0.179183 & 0.291227 & 0.391475 & 0.484470 & 0.713255 & 0.714860 & 0.891704 & 1.179707 \\
$30^{\circ}$ & 0.230649 & 0.405803 & 0.559769 & 0.701630 & 1.048864 & 1.051296 & 1.318931 & 1.754354 \\
$40^{\circ}$ & 0.227988 & 0.474040 & 0.683003 & 0.873363 & 1.335650 & 1.338878 & 1.693671 & 2.270034 \\
$50^{\circ}$ & & 0.484297 & 0.751109 & 0.989703 & 1.562439 & 1.566421 & 2.003338 & 2.711604 \\
$60^{\circ}$ & & 0.436654 & 0.760284 & 1.041849 & 1.707893 & 1.712500 & 2.216968 & 3.032690 \\
$70^{\circ}$ & & & 0.710511 & 1.041468 & 1.805893 & 1.811139 & 2.383994 & 3.306937 \\
$80^{\circ}$ & & & & 0.981268 & 1.835994 & 1.841797 & 2.473322 & 3.486083 \\
$90^{\circ}$ & & & & & 1.803875 & 1.810139 & 2.488790 & 3.570877 \\
$100^{\circ}$ & & & & & & 1.736970 & 2.446270 & 3.570306 \\
\hline
\end{tabular}

TABLE 3. Variation of $N u_{x} \operatorname{Re}_{x}^{-1 / 2}$ for several values of $x$ and $\gamma$

\begin{tabular}{ccccccccc}
\hline$x \mid \gamma$ & -1.0 & -0.5 & 0.0 & 0.5 & 1.85 & 1.86 & 3.0 & 5.0 \\
\hline $0^{\circ}$ & 0.443672 & 0.477262 & 0.503608 & 0.525634 & 0.572510 & 0.572900 & 0.604045 & 0.648163 \\
$10^{\circ}$ & 0.438992 & 0.473176 & 0.499613 & 0.521524 & 0.567710 & 0.568003 & 0.598224 & 0.640415 \\
$20^{\circ}$ & 0.427674 & 0.463505 & 0.490240 & 0.511909 & 0.556302 & 0.556578 & 0.584639 & 0.622303 \\
$30^{\circ}$ & 0.406467 & 0.446195 & 0.473732 & 0.495120 & 0.536520 & 0.536767 & 0.591082 & 0.590802 \\
$40^{\circ}$ & 0.374394 & 0.422503 & 0.451837 & 0.473157 & 0.510930 & 0.511140 & 0.530618 & 0.549921 \\
$50^{\circ}$ & & 0.392445 & 0.425515 & 0.447360 & 0.481465 & 0.481633 & 0.495600 & 0.502721 \\
$60^{\circ}$ & & 0.359373 & 0.398976 & 0.422223 & 0.453596 & 0.453727 & 0.462621 & 0.458140 \\
$70^{\circ}$ & & & 0.365687 & 0.392323 & 0.421937 & 0.422031 & 0.425489 & 0.407938 \\
$80^{\circ}$ & & & & 0.361169 & 0.391248 & 0.391313 & 0.390100 & 0.360381 \\
$90^{\circ}$ & & & & & 0.362382 & 0.362430 & 0.357747 & 0.317647 \\
$100^{\circ}$ & & & & & & 0.338594 & 0.332101 & 0.284884 \\
\hline
\end{tabular}

occurs at the cylinder surface for certain positive and negative values of $\gamma$, such that when $\gamma>0$, it assists the flow; the cylinder is heated and when $\gamma<0$, it opposes the flow; the cylinder is cooled. The boundary layer separation is delayed in the range of $0 \leq x \leq 100^{\circ}$ for sufficiently large values of assisting flow $\gamma(>0)$. As for sufficiently strong opposing flow $\gamma(<0)$, the buoyancy forces are likely to slow down the fluid flow, therefore, the point of separation is conveyed closer to the lower stagnation point. At this point, $\gamma=-1.0$ is the value at which the boundary layer separates and no boundary layer exists below that value (Merkin 1977). Furthermore, the boundary layer, which firstly gives no separation, lies between $1.85<\gamma_{c}<1.86$.

The respective velocity $f^{\prime}(y)$ and temperature $\theta(y)$ profiles in Figures 2 and 3 are explored on the diverse values of ratio of relaxation to retardation times, $\lambda$. In Figure 2, the polymer flow is significantly boosted near the cylinder surface resulting from the increasing $\lambda$. This is because, the increase of $\lambda$ indicates a rise in the relaxation time (time required for the material to retain its original position) and a decline in the retardation time (time required for the material to respond to deformation). Here, relaxation time is dominantly raised in comparison to the declination of retardation time, thus, leads to the acceleration of polymer flow along with momentum boundary layer thickness. Note that $\lambda$ is arising in both (11) and (12), i.e. $\frac{1}{1+\lambda} f^{\prime \prime \prime}, \frac{\lambda_{2}}{1+\lambda}\left(f^{\prime \prime}\right)^{2},-\frac{\lambda 2}{1+\lambda} f f^{(i v)}$, $-x \frac{E c}{1+\lambda}\left(f^{\prime \prime}\right)^{2},-x \lambda_{2} \frac{E c}{1+\lambda} f^{\prime}\left(f^{\prime \prime}\right)^{2}$ and many more, therefore, such significant effects on the polymer flow are predictable. As shown in Figure 3, with greater polymer relaxation time, the effect of $\lambda$ is to reasonably reduce the temperature accompanied by the thickness of the thermal boundary layer.

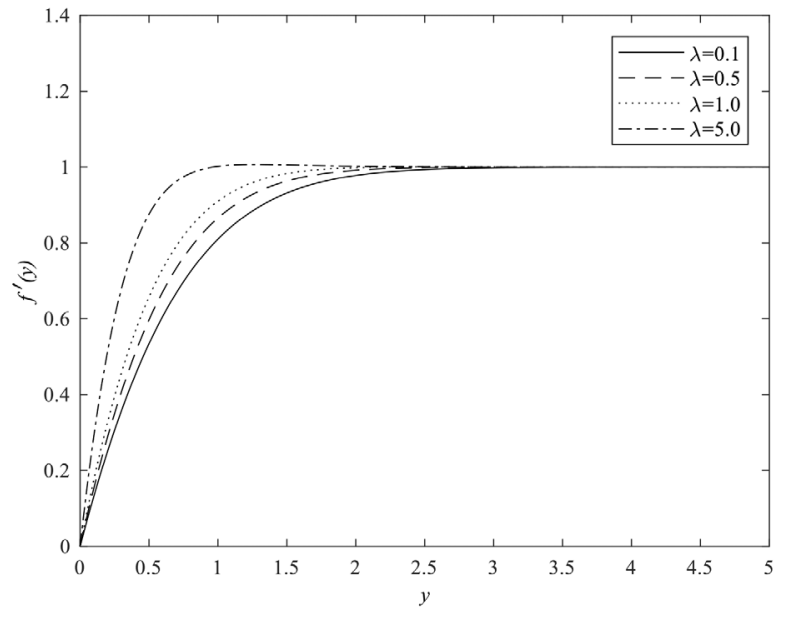

FIGURE 2. Influence of $\lambda$ on $f^{\prime}(y)$ 


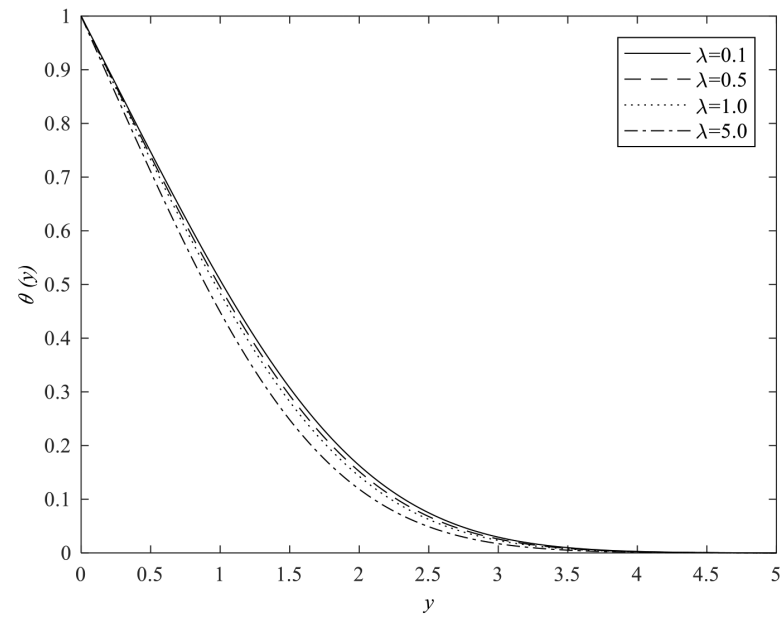

FIGURE 3. Influence of $\lambda$ on $\theta(y)$

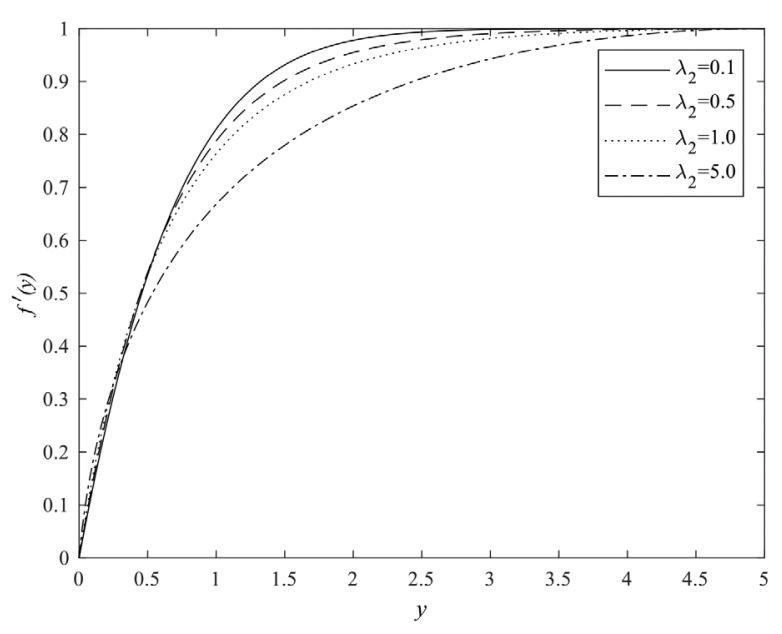

FIGURE 4. Influence of $\lambda_{2}$ on $f^{\prime}(y)$

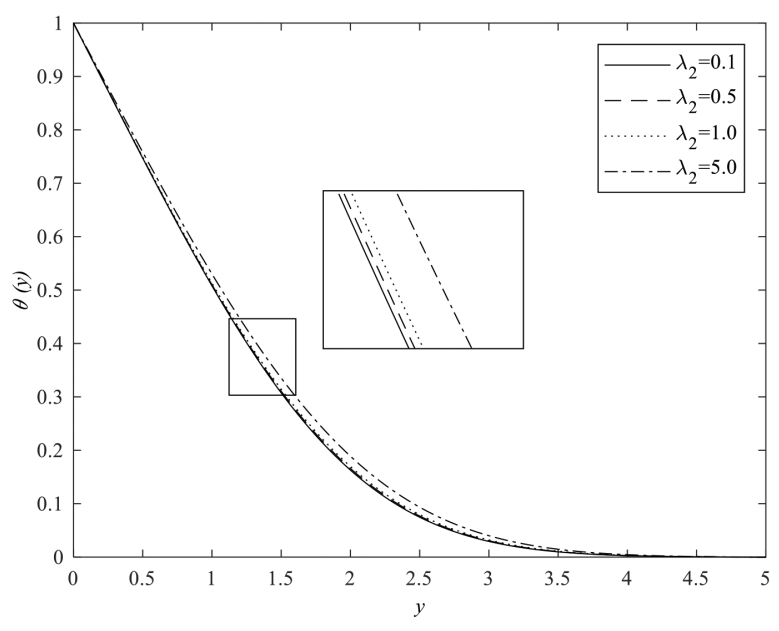

FIGURE 5. Influence of $\lambda_{2}$ on $\theta(y)$

or air. Here, a parameter that is responsible for roughly certifying which process is leading is Pr. Pr is termed as the relationship between momentum and thermal diffusivities, where the momentum diffusivity is greater for larger Pr and lesser for smaller Pr. Obviously, both temperature and thermal boundary layer thickness are lesser for larger $\mathrm{Pr}$ and greater for smaller Pr. Larger Pr value signifies highly viscous fluid with low thermal conductivity. Low thermal conductivity tends to reduce the energy transfer ability that is useful for reducing thermal boundary layer and accordingly, the transfer of heat will be finally less convective (Hayat et al. 2015; Salleh et al. 2010).

Figures 7 and 8 elucidate the effect of $\lambda$ on $C_{f} \operatorname{Re}_{x}^{1 / 2}$ and $N u_{x} \mathrm{Re}_{x}^{-1 / 2}$. In Figure 7, the $C_{f} \mathrm{Re}_{x}^{1 / 2}$ is apparently a declining function of $\lambda$. This finding can be linked to Figure 2, where the increase of relaxation time encourages the material to be more relaxed and friction of fluid will lastly be less effective. The impact of relaxation time has otherwise guided the increasing function of $N u_{x} \mathrm{Re}_{x}^{-1 / 2}$ over dissimilar $\lambda$, which physically means the convection heat transfer is more significant than the conduction (Figure 8). Here, depending on the fluid types such as mercury, water, oil 


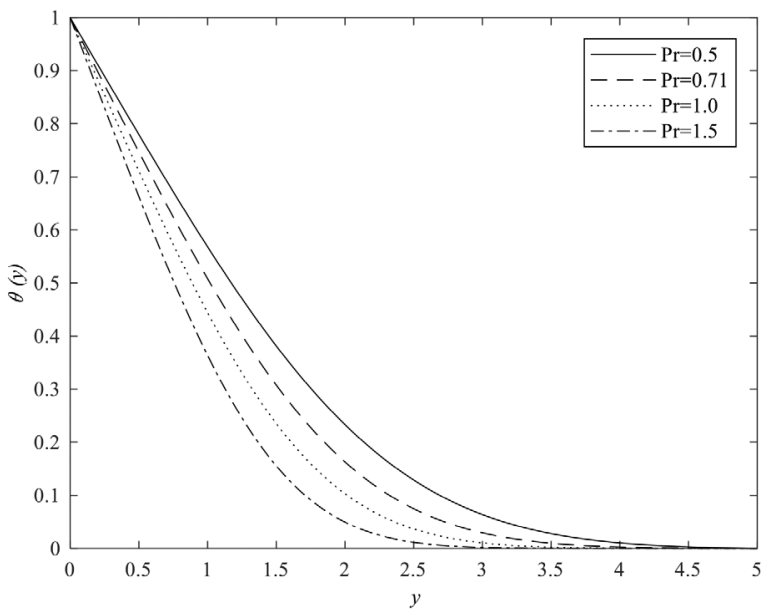

FIGURE 6. Influence of $\operatorname{Pr}$ on $\theta(y)$

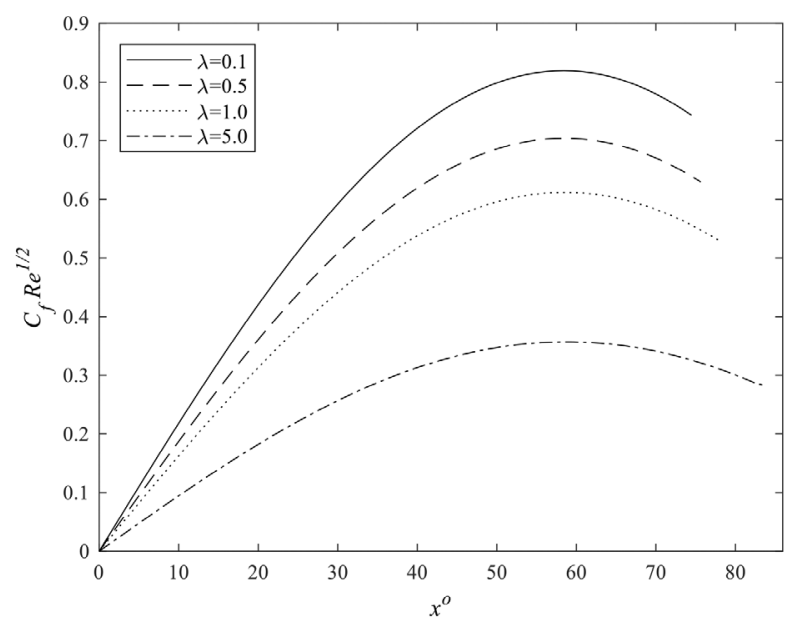

FIGURE 7. Influence of $\lambda$ on $C_{f} \operatorname{Re}_{x}^{1 / 2}$

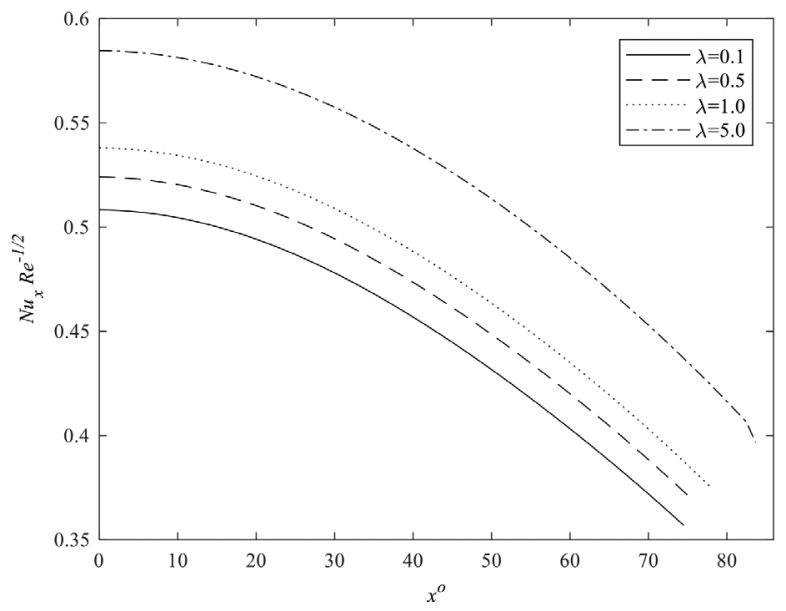

FIGURE 8. Influence of $\lambda$ on $N u_{x} \operatorname{Re}_{x}^{-1 / 2}$

the boundary layer separation for both figures are found to defer the most when $\lambda=5.0$ at $x=89.38^{\circ}$.

Figures 9 and 10 explain the effect of $\lambda_{2}$ on $C_{f} \operatorname{Re}_{x}^{1 / 2}$ and $N u_{x} \operatorname{Re}_{x}^{-1 / 2}$ versus $x$, respectively. From Figure 9,

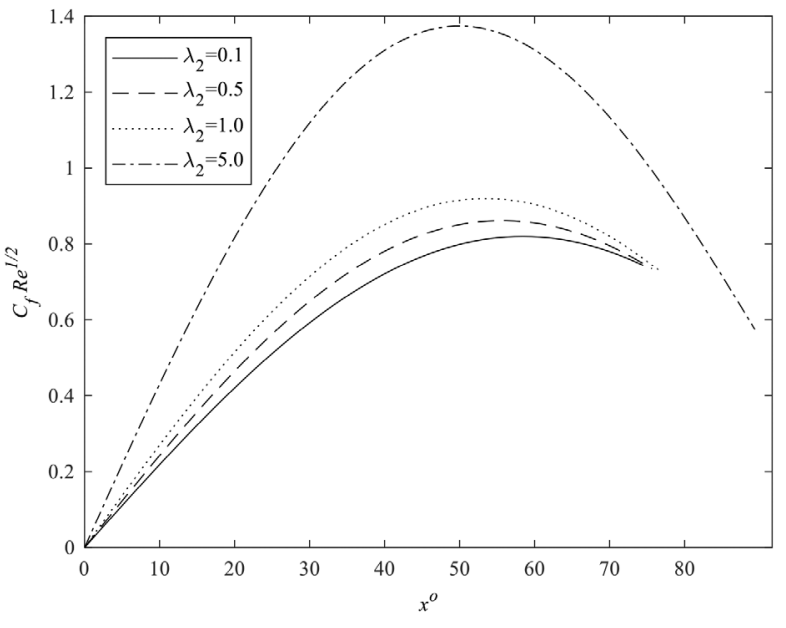

FIGURE 9. Influence of $\lambda_{2}$ on $C_{f} \operatorname{Re}_{x}^{1 / 2}$

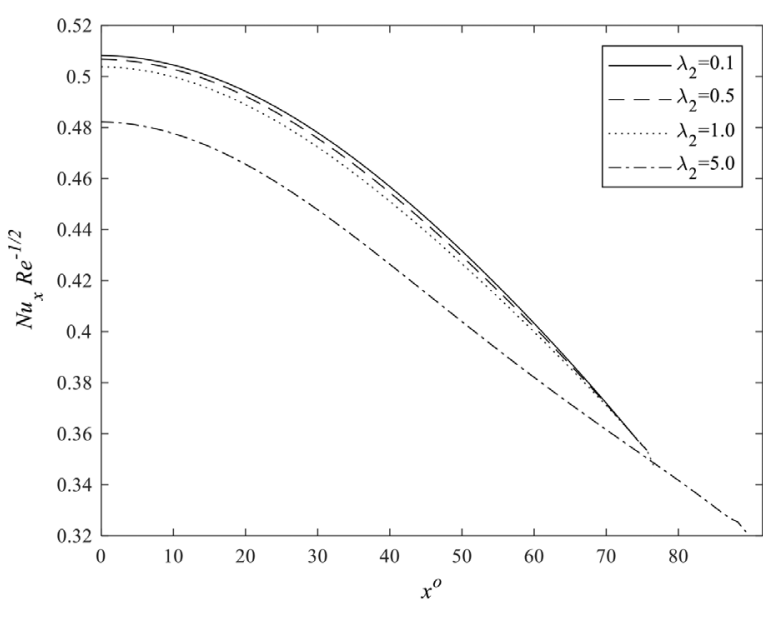

FIGURE 10. Influence of $\lambda_{2}$ on $N u_{x} \operatorname{Re}_{x}^{-1 / 2}$

the $C_{f} \mathrm{Re}_{x}^{1 / 2}$ is considerably boosted in response to the increasing values of $\lambda_{2}$. This is owing to the high fluid viscosity coupled with high wall shear stress that give rise to the friction within the fluid and between the fluid and the wall. The $N u_{x} \operatorname{Re}_{x}^{-1 / 2}$ is alternatively deteriorated in Figure 10 due to the viscous and elastic behaviours displayed by parameter $\lambda_{2}$. This also suggests that the convective heat transfer from the cylinder surface depletes progressively. Similar to Figures 7 and $8, \lambda_{2}=5.0$ and $x=89.38^{\circ}$ are the farthest values at which the boundary layer separation deferred.

Figures 11 and 12 show the impact of the Eckert number $E c$ on $C_{f} \mathrm{Re}_{x}^{1 / 2}$ and $N u_{x} \mathrm{Re}_{x}^{-1 / 2}$. Ec is a dimensionless number used to describe heat dissipation. Since $E c$ is the ratio of kinetic energy at the wall to the specific enthalpy difference between the wall and the fluid, therefore, increasing the kinetic energy will enhance fluid friction and thereby, increasing the $C_{f} \operatorname{Re}_{x}^{1 / 2}$ (Figure 11). In addition, as the position of $x$ increases, the $C_{f} \mathrm{Re}_{x}^{1 / 2}$ values are observed to be unique initially, but then start to gradually increase after $x=30^{\circ}$. In Figure 12, it is seen that an increase of $E c$ results in the strong deceleration of the $N u_{x} \mathrm{Re}_{x}^{-1 / 2}$. Due to 


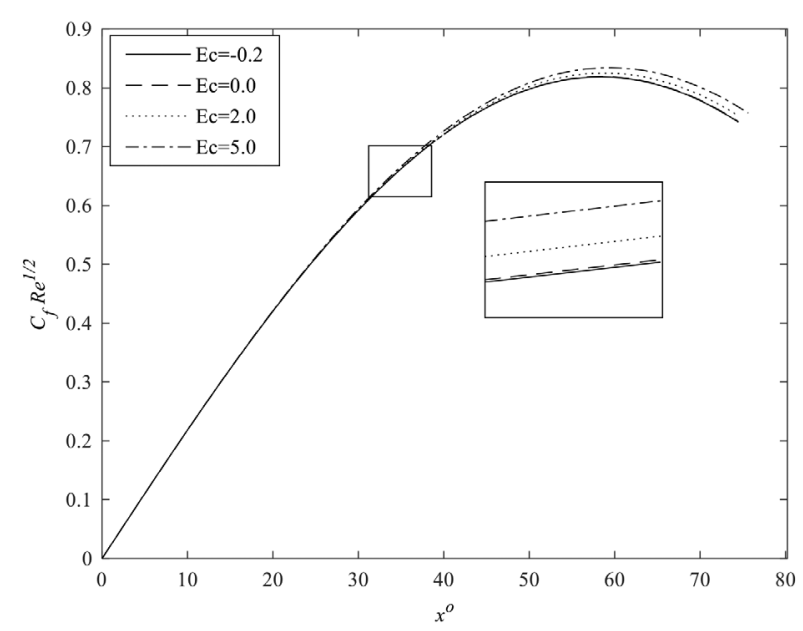

FIGURE 11. Influence of $E c$ on $C_{f} \operatorname{Re}_{x}^{1 / 2}$

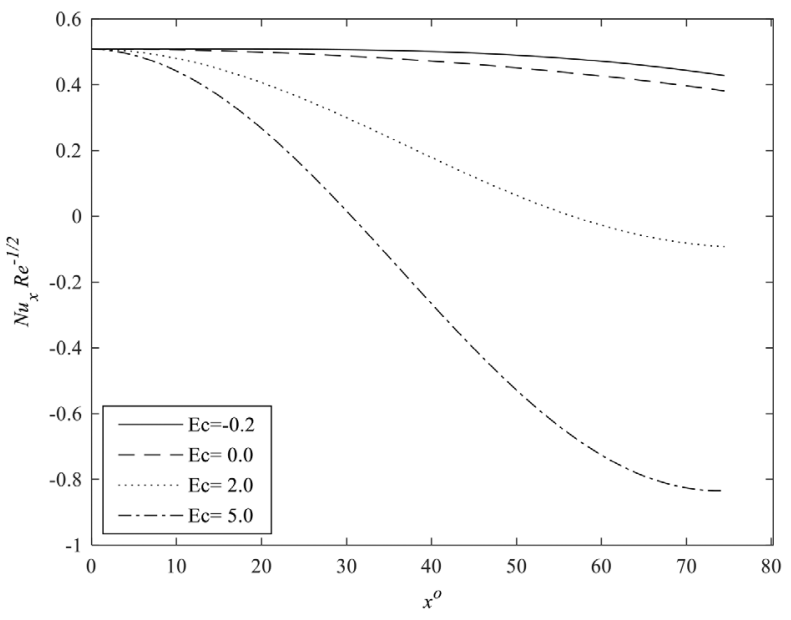

FIGURE 12. Influence of $E c$ on $N u_{x} \mathrm{Re}_{x}^{-1 / 2}$

the heat created by the dissipative effects, the convective heat transfer is lessened severely down to a condition in which the heat flow is actually reversed. As shown in the figure, when $E c=2.0$ and 5.0, the numerical computations give negative values of $N u_{x} \mathrm{Re}_{x}^{-1 / 2}$, that physically suggests a reverse direction of flow convection between the cylinder wall and the surrounding fluid. This finding concurs well with the theory proposed by Geropp (1969). Referring to equation (15), it is interesting to remark that both velocity and temperature profiles do not pronounce any effect on the $E c$ as it discontinues at $x=0$.

\section{CONCLUSION}

The problem of steady mixed convection boundary layer flow over a horizontal circular cylinder filled in a Jeffrey fluid with viscous dissipation effect is studied. The mathematical formulation is initially written in dimensional partial differential equations followed by the employment of the non-dimensional variables. Then, the resulting non-dimensional partial differential equations that are subjected to physically appropriate boundary conditions are obtained and solved numerically using the Keller-box method. This study determines quite evidently how the mixed convection parameter, Jeffrey fluid parameters and the Prandtl and Eckert numbers affect the fluid flow and heat transfer features as well as the boundary layer separation. For the mixed convection parameter, both the cases of $\gamma>0,\left(T_{w}>T_{\infty}\right)$ assisting flow (heated cylinder) and $\gamma<0,\left(T_{w}<T_{\infty}\right)$ opposing flow (cooled cylinder) are examined. For the sufficiently heated cylinder, the boundary layer separation is delayed in the range of $0 \leq x \leq 100^{\circ}$. Meanwhile, for the sufficiently cooled cylinder, the boundary layer separation is conveyed closer to the lower stagnation point and the boundary layer separates at $\gamma=-1.0$. Both of the Jeffrey fluid parameters, i.e. the ratio of relaxation to retardation times and the Deborah number, show contradictory behaviours on the velocity and temperature profiles as well as the skin friction coefficient and Nusselt number. The increase of the Prandtl number causes the decrease in the temperature profile, while the increase of the Eckert number causes a slight increment of the skin friction coefficient and decrement of the Nusselt number. No effects are found for both velocity and temperature profiles of the Eckert number at the lower stagnation point of the cylinder.

\section{ACKNOWLEDGEMENTS}

The authors are thankful to the Universiti Malaysia Pahang (UMP) (PGRS1703100 and RDU170358) for the financial support.

\section{REFERENCES}

Anwar, I., Amin, N. \& Pop, I. 2008. Mixed convection boundary layer flow of a viscoelastic fluid over a horizontal circular cylinder. International Journal of Non-Linear Mechanics 43(9): 814-821.

Baaijens, F.P., Selen, S.H., Baaijens, H.P., Peters, G.W. \& Meijer, H.E. 1997. Viscoelastic flow past a confined cylinder of a low density polyethylene melt. Journal of Non-Newtonian Fluid Mechanics 68(2): 173-203.

Das, K., Acharya, N. \& Kundu, P.K. 2015. Radiative flow of MHD Jeffrey fluid past a stretching sheet with surface slip and melting heat transfer. Alexandria Engineering Journal 54(4): 815-821.

Ferdows, M., Afify, A. \& Tzirtzilakis, E. 2017. Hall current and viscous dissipation effects on boundary layer flow of heat transfer past a stretching sheet. International Journal of Applied and Computational Mathematics 3(4): 3471-3482.

Gaffar, S.A., Prasad, V.R., Reddy, E.K. \& Bég, O.A. 2015. Thermal radiation and heat generation/absorption effects on viscoelastic double-diffusive convection from an isothermal sphere in porous media. Ain Shams Engineering Journal 6(3): 1009-1030.

Gebhart, B. 1962. Effects of viscous dissipation in natural convection. Journal of Fluid Mechanics 14(02): 225-232.

George, K.E. 2009. 2 - Non-Newtonian fluid mechanics and polymer rheology. In Advances in Polymer Processing, edited by Thomas, S. \& Yang, Weimin. Cambridge: Woodhead Publishing. pp: 13-46. 
Geropp,D. 1969. Der turbulente wärmeübergang am rotierenden zylinder. Archive of Applied Mechanics 38(4): 195-203.

Hayat, T., Ashraf, M.B., Shehzad, S.A. \& Bayomi, N.N. 2015. Mixed convection flow of viscoelastic nanofluid over a stretching cylinder. Journal of the Brazilian Society of Mechanical Sciences and Engineering 37(3): 849-859.

Kasim, A.R.M., Mohammad, N.F., Shafie, S. \& Pop, I. 2013. Constant heat flux solution for mixed convection boundary layer viscoelastic fluid. Heat and Mass Transfer 49(2): 163-171.

Merkin, J. 1977. Mixed convection from a horizontal circular cylinder. International Journal of Heat and Mass Transfer 20(1): 73-77.

Merkin, J. \& Pop, I. 1988. A note on the free convection boundary layer on a horizontal circular cylinder with constant heat flux. Heat and Mass Transfer 22(1): 79-81.

Mohamed, M.K.A., Salleh, M.Z., Noar, N.\& Ishak, A. 2016. The viscous dissipation effects on the mixed convection boundary layer flow on a horizontal circular cylinder. Jurnal Teknologi 78(4-4): 73-79.

Morini, G.L. 2013. Viscous dissipation. Encyclopedia of Microfluidics and Nanofluidics Boston, MA: Springer US. pp: $1-15$.

Nazar, R. 2003. Mathematical models for free and mixed convection boundary layer flows of micropolar fluids.Tesis $\mathrm{PhD}$ Universiti Teknologi Malaysia, Malaysia (Unpublished).

Nazar, R., Amin, N. \& Pop, I. 2003. Mixed convection boundarylayer flow from a horizontal circular cylinder in micropolar fluids: Case of constant wall temperature. International Journal of Numerical Methods for Heat \& Fluid Flow 13(1): 86-109.

Prasad, V.R., Gaffar, S.A., Reddy, E.K. \& Bég, O.A. 2014. Flow and heat transfer of Jeffreys non-Newtonian fluid from horizontal circular cylinder. Journal of Thermophysics and Heat Transfer 28(4): 764-770.

Prasad, V.R., Gaffar, S.A., Reddy, E.K. \& Bég, O.A. 2015. Numerical study of non-Newtonian Jeffreys fluid from a permeable horizontal isothermal cylinder in non-Darcy porous medium. Journal of the Brazilian Society of Mechanical Sciences and Engineering 37(6): 1765-1783.

Rao, A.S., Nagendra, N. \& Prasad, V.R. 2015. Heat transfer in a Non-Newtonian Jeffrey's fluid over a Non-Isothermal Wedge. Procedia Engineering 127: 775-782.

Rashad, A., Chamkha, A. \& Modather, M. 2013. Mixed convection boundary-layer flow past a horizontal circular cylinder embedded in a porous medium filled with a nanofluid under convective boundary condition. Computers \& Fluids 86: $380-388$
Rotte, J. \& Beek,W. 1969. Some models for the calculation of heat transfer coefficients to a moving continuous cylinder. Chemical Engineering Science 24(4): 705-716.

Salleh, M.Z., Nazar, R. \& Pop, I. 2010. Boundary layer flow and heat transfer over a stretching sheet with Newtonian heating. Journal of the Taiwan Institute of Chemical Engineers 41(6): 651-655.

Subba, R.A., Ramachandra, P.V., Rajendra, P., Sasikala, M. \& Anwar, B.O. 2017. Numerical study of non-Newtonian polymeric boundary layer flow and heat transfer from a permeable horizontal isothermal cylinder. Frontiers in Heat and Mass Transfer (FHMT) 9(1).

Yirga, Y. \& Shankar, B. 2013. Effects of thermal radiation and viscous dissipation on magnetohydrodynamic stagnation point flow and heat transfer of nanofluid towards a stretching sheet. Journal of Nanofluids 2(4): 283-291.

Zin, N.A.M., Khan, I. \& Shafie, S. 2017. Exact and numerical solutions for unsteady heat and mass transfer problem of Jeffrey fluid with MHD and Newtonian heating effects. Neural Computing and Applications. doi.org/10.1007/ s00521-017-2935-6.

Syazwani Mohd Zokri, Nur Syamilah Arifin, Muhammad Khairul Anuar Mohamed,

Abdul Rahman Mohd Kasim \& Mohd Zuki Salleh*

Faculty of Industrial Sciences \& Technology

Universiti Malaysia Pahang

26300 UMP Kuantan, Pahang Darul Makmur

Malaysia

Nurul Farahain Mohammad

Department of Computational and Theoretical Sciences

Kulliyyah of Science

International Islamic University Malaysia

25200 Kuantan, Pahang Darul Makmur

Malaysia

*Corresponding author; email: zuki@ump.edu.my

Received: 20 July 2017

Accepted: 27 February 2018 